\title{
Medical Treatment in Cushing's Syndrome: Dopamine Agonists and Cabergoline
}

\author{
Patrick Petrossians Anne-Sophie Thonnard Albert Beckers \\ Endocrinology, University of Liège, Liège, Belgium
}

\section{Key Words}

Dopamine agonists $\cdot$ Cabergoline $\cdot$ Cushing's disease $\cdot$ Adrenocorticotropic hormone $\cdot$ Cortisol $\cdot$ Adenoma . Ectopic

\begin{abstract}
Dopamine (DA) is a catecholamine with a wide range of functions and whose five subtype receptors are found in different organs where they exert a mainly inhibitory action. Since this action may also appear in a number of secretory tumors in various locations, DA agonists have elicited some interest as a medical treatment for hypercorticism. Non-iatrogenic Cushing's syndromes are due in 70\% of the cases to a pituitary adrenocorticotropic hormone (ACTH)-producing adenoma, and, less frequently, to an adrenal adenoma or an ectopic ACTH secretion by a neuroendocrine tumor. First-line treatment in Cushing's syndrome consists of the surgical removal of the secreting tumor. However, surgery may not achieve a complete cure in a number of cases, hence emphasizing the potential benefit of a medical complementary treatment, which could also benefit patients as an alternative approach, either when waiting for, or when the patient is not eligible for surgery. Studies of corticotropic adenomas have shown that $80 \%$ of these tumors express $D 2$ receptors. Clinical trials of DA agonists in Cushing's disease have shown an inhibitory effect of these drugs with an inhibition of ACTH secretion and/or a decrease of tumor size. There are only a
\end{abstract}

few cases of documented use of DA agonists in ectopic ACTH secretion, but when the tumor expresses DA receptors, DA agonists may represent a useful complementary treatment. DA receptors are also expressed in normal and tumoral adrenals, suggesting a potential use of DA agonists in Cushing's syndrome secondary to adrenal tumors. However, clinical data regarding this specific situation are very scarce, maybe due to the relatively high rate of surgical cure of adrenal adenomas. In conclusion, DA agonists represent a potential preparatory or complementary treatment for endogenous Cushing's syndrome, especially in Cushing's disease. These compounds may be underused as suggested by the scarce number of publication and case reports in the literature. In the future, association of these drugs with somatostatin analogs may also prove beneficial.

Copyright $\odot 2010$ S. Karger AG, Basel

\section{Introduction}

Cushing's syndrome [1] is a pathology which is often easy to suspect, sometimes difficult to demonstrate, frequently with elusive etiology, and seldom treated by the clinician. Indeed in most cases, surgery is the first-line treatment of noniatrogenic Cushing's syndrome, whether due to a pituitary or adrenal adenoma or a paraneoplastic adrenocorticotropic hormone (ACTH) secretion. This is probably why medical treatment of Cushing's syndrome

\section{KARGER}

Fax +41613061234 E-Mail karger@karger.ch www.karger.com
(C) 2010 S. Karger AG, Base

0028-3835/10/09258-0116\$26.00/0

Accessible online at:

www.karger.com/nen
Albert Beckers

Endocrinologie, $\mathrm{CHU}$

Domaine Universitaire du Sart Tilman

BE-4000 Liege (Belgium)

Tel. +32 4366 7083, Fax +34 4366 7261, E-Mail albert.beckers@ @hu.ulg.ac.be 
has not elicited a lot of interest from the endocrine community in comparison to other conditions like acromegaly. Medical treatment is, however, mandatory in some situations. Surgery may not be always curative. Sometimes patients' general condition contraindicates surgery, which may be delayed, calling for a preparatory or secondary medical treatment.

Historically, compounds interfering with the synthesis of cortisol were the main drugs used in these patients. Later, drugs interfering with the physiological control of hormone secretion have been tested in vitro or in vivo. Dopamine (DA) agonists are one of these new potential treatments [2].

\section{Physiology}

DA is a catecholamine hormone with a short half-life of about $1 \mathrm{~min}$. It has a wide range of physiological properties, acting as a neurotransmitter, controlling hormonal secretions, cardiovascular tone and renal filtration. The effect of DA is the result of the activity of its receptor (DR) $[3,4]$ which belongs to the family of G-protein-coupled receptors. G-protein-coupled receptors are located in the cells' membranes and comprise seven transmembranes domains. DRs are made of five subtypes D1-D5 which are divided in two groups: D1-like (D1 and D5) and D2-like (D2, D3, D4). D1-like receptors are generally considered as triggering a stimulatory effect, whereas D2-like receptors are generally associated with an inhibitory action. The D2 receptor is itself made of two isoforms: the short and the long isoforms.

\section{Localization of DA Receptors}

DA receptors have been demonstrated in a variety of organs [5], on par with their wide physiologic effects. They are present in the brain, the pituitary, the adrenals, the kidneys, the gastrointestinal track and the cardiovascular system. These receptors being present in the neuroendocrine system, one may expect them to be expressed in tumors deriving from these tissues and, possibly, to exert an inhibitory effect when activated [4].

\section{Pituitary}

Immunohistochemistry, receptor-ligand-binding and RT-PCR studies have demonstrated that D2-type receptors may be present in up to $80 \%$ of pituitary corticotropic adenomas. The presence of these receptors correlated quite well with in vitro ACTH secretion control: tumoral cells that highly expressed D2 receptors showed an inhibition of ACTH secretion of 43-60\%, whereas cells that did not express the D2 receptor did not respond to DA agonists [6].

\section{Ectopic}

A study on a small cell lung cancer cell [7] line showed an inhibition of pro-opiomelanocortin mRNA by bromocriptine. In a series of six carcinoid tumors (four lung, one pancreas and one thymic), five expressed D2 receptors on immunohistochemistry [8].

\section{Adrenals}

Both D1- and D2-type receptors are present in normal adrenals, where they play a role in the secretion of cortisol, aldosterone and androgens. In tumoral cells, both D2 and D4 subtypes are expressed. However, adenomas expressed both D2 isoforms, whereas carcinomas expressed only the long D2 isoform [9].

\section{Clinics}

\section{Cushing's Disease}

The first studies of DA agonists in Cushing's disease were performed with bromocriptine. A decrease in ACTH production was generally observed in $50 \%$ of the cases; however, this effect did not appear to be very strong and was maintained for longer term only in a smaller subset of cases [10]. Better results were expected with cabergoline which has a higher binding capacity to D2 receptors and a longer half-life.

The first cases in the literature are two case reports describing tumor shrinkage in a silent ACTH-adenoma expressing D2 receptors [11] and decreased ACTH with tumor shrinkage in a secreting adenoma [12]; both patients were treated with cabergoline.

Pivonello and co-workers studied the use of cabergoline in short- [6] and long-term [13] treatment in 20 patients. In the short term (3 months), urinary free cortisol was normalized or decreased in 15 patients. Ten of these patients showed a remission during the long-term treatment (12-24 months). Clinical data showed good correlation with the expression of $\mathrm{D} 2$ receptors by tumoral cells.

\section{Ectopic ACTH Secretion}

Pivonello et al. [8] describe 6 cases with ACTH-secreting carcinoid tumors who had been operated. Three of these patients were not cured and therefore treated with 
Table 1. Cabergoline used in Cushing's syndrome

\begin{tabular}{|c|c|c|c|c|c|c|}
\hline First author, year & $\begin{array}{l}\text { Cases } \\
\mathrm{n}\end{array}$ & $\begin{array}{l}\text { Dose mg/ } \\
\text { week }\end{array}$ & $\begin{array}{l}\text { Duration } \\
\text { months }\end{array}$ & Biological results & Tumor & Notes \\
\hline \multicolumn{7}{|l|}{ Cushing's syndrome } \\
\hline Petrossians, 2001 [11] & 1 & 1.75 & 12 & NA & shrinkage & silent adenoma \\
\hline Miyoshi, 2004 [12] & 1 & $0.25-0.5$ & 6 & decreased ACTH & shrinkage & \\
\hline Pivonello, 2004 [6] & 20 & $1-3$ & 3 & $\begin{array}{l}\text { UFC: } 40 \% \text { normalization, } \\
20 \% \text { decrease }\end{array}$ & NA & 5 micro-, 15 macroadenomas \\
\hline Illouz, 2006 [21] & 3 & $1-3$ & $1-9$ & UFC: normalized in 2 cases & no change & \\
\hline Godbout, 2007 [22] & 8 & $0.75-3$ & $20-28$ & $\begin{array}{l}\text { UFC: normalized in } 38 \% \text {, } \\
\text { decreased in } 38 \%\end{array}$ & shrinkage & \\
\hline Pivonello, 2009 [13] & 20 & $1-7$ & $3-24$ & UFC: normalized in 10 cases & NA & $\begin{array}{l}\text { long-term results of patients } \\
\text { described in } 2004\end{array}$ \\
\hline Vilar, 2009 [23] & 12 & $2-3$ & 6 & UFC: normalized in 3 cases & NA & $\begin{array}{l}\text { ketoconazole combined with } \\
\text { cabergoline normalized UFC } \\
\text { in } 6 \text { patients out of } 9 \text { remain- } \\
\text { ing patients }\end{array}$ \\
\hline $\begin{array}{l}\text { Ectopic ACTH secretion } \\
\text { Pivonello, } 2007 \text { [8] }\end{array}$ & 3 & 3.5 & 6 & UFC: normalized in 2 cases & NA & 1 escape \\
\hline
\end{tabular}

$\mathrm{NA}=$ Not available; UFC $=$ urinary free cortisol.

cabergoline ( $3.5 \mathrm{mg} /$ week for 6 months). Two of these 3 patients normalized their urinary free cortisol, although 1 of them who had the weakest D2 isoform expression exhibited treatment escape.

\section{Adrenal Adenomas}

There are currently no firm data related to the use of DA agonists in adrenal adenomas causing Cushing's syndrome. Indeed, in these pathologies, treatment is mainly surgical with a relatively high cure rate.

\section{Discussion}

A summary of the available publications on the use of cabergoline in Cushing's syndrome is represented in table 1. Due to its higher affinity to D2-type receptors and longer half-life, this compound may play a more important role in the medical treatment of Cushing's syndrome than its predecessor bromocriptine. However, although the interest in the medical use of DA agonists is not new, one cannot fail to observe the scarcity of publications on this subject. There may be two explanations for the lack of data. Adrenal adenomas represent a small percentage of Cushing's syndromes. They are usually treated surgically and, in the case of true benign adenomas, with good surgical results, thus alleviating the need of com- plementary medical therapy. Ectopic ACTH secretion by a neuroendocrine tumor represents a small group of Cushing's syndromes, and is also treated surgically. When the originating tumor is correctly localized, up to $80 \%$ of surgical success is described [14]. When the tumor is not localized or surgery is not curative, patients undergo bilateral adrenalectomy, and they may also be treated by steroidogenesis inhibitors or chemotherapy. For these tumors, DA agonists may thus appear as an unusual therapeutic alternative and not be envisioned in everyday practice.

For Cushing's disease, however, the scarcity of the literature may seem more surprising. True, ACTH secreting pituitary adenomas represent only $\pm 7 \%$ of pituitary adenomas (with acromegaly $\pm 12 \%$ and prolactinomas $\pm 50 \%$, with a prevalence of $1: 1,064$ for pituitary adenomas [15]), but they are usually explored and treated by endocrinologists experienced in pituitary tumors and who routinely use DA agonists. So one may expect to see more trials with cabergoline in Cushing's disease.

The available literature for this topic is mainly made of case reports and four series for Cushing's disease, one series in ectopic ACTH secretion and, to the authors' knowledge, no series in adrenal adenomas. It is difficult to assess if these data represent the only therapeutic trials that have been made in different centers. One could not exclude that a number of cases have not been published 
(either because of the lack of good results or the lack of interest in the publication process) $[16,17]$. Another point is that study durations are rather short, knowing that a secondary treatment could imply a life-long use. Nonetheless, despite these restrictions, the available data do encourage us to try DA agonists when looking for a medical treatment of Cushing's disease. And, in the case of Cushing's syndrome, the in vitro data at least, may legitimize therapeutic trials associating DA agonists. One point of concern, however, is the safety of cabergoline in chronic treatment. Cardiac valve disease has been associated with the use of DA agonists in Parkinson disease $[18,19]$. These patients were receiving doses of cabergoline higher (avg. dose of $3.6 \mathrm{mg} /$ day) than those routinely used in endocrine practice. A study of endocrinology patients taking cabergoline for 12-228 months with doses between 0.25 and $4.5 \mathrm{mg} /$ week did not show a significant increase of clinically relevant cardiac valve disorders [20].

\section{Conclusions}

A review of the recent literature shows a scarce number of publications and an even scarcer series on the use of DA agonists in Cushing's syndrome [21-23]. The main clinical data concern Cushing's disease. Less data are available regarding ectopic ACTH secretion and basically none on cortisol secreting adrenal adenomas. In vitro studies showing the presence of D2-type receptors in tumors of different origin sometimes with a good correlation with in vitro and even in vivo response to DA agonists suggests that these compounds may present a therapeutic interest as complementary or alternative treatment is some cases of noniatrogenic Cushing's syndrome. Some other options may rely in the joint use of DA agonists with somatostatin analogs or with some new chimeric molecules.

\section{Disclosure Statement}

The authors have nothing to disclose.

\section{References}

$\rightarrow 1$ Newell-Price J, Bertagna X, Grossman AB, Nieman LK: Cushing's syndrome. Lancet 2006;367:1605-1617.

$\checkmark 2$ de Bruin C, Feelders RA, Lamberts SW, Hofland LJ: Somatostatin and dopamine receptors as targets for medical treatment of Cushing's syndrome. Rev Endocr Metab Disord 2009;10:91-102.

-3 Ferone D, Gatto F, Arvigo M, et al: The clinical-molecular interface of somatostatin, dopamine and their receptors in pituitary pathophysiology. J Mol Endocrinol 2009;42: 361-370.

-4 Pivonello R, Ferone D, Lombardi G, et al: Novel insights in dopamine receptor physiology. Eur J Endocrinol 2007;156:S13-S21.

5 Missale C, Nash SR, Robinson SW, Jaber M, Caron MG: Dopamine receptors: from structure to function. Physiol Rev 1998;78: 189-225.

-6 Pivonello R, Ferone D, de Herder WW, et al: Dopamine receptor expression and function in corticotroph pituitary tumors. J Clin Endocrinol Metab 2004;89:2452-2462.

7 Farrell WE, Clark AJ, Stewart MF, Crosby SR, White A: Bromocriptine inhibits proopiomelanocortin mRNA and ACTH precursor secretion in small cell lung cancer cell lines. J Clin Invest 1992;90:705-710.

-8 Pivonello R, Ferone D, de Herder WW, et al: Dopamine receptor expression and function in corticotroph ectopic tumors. J Clin Endocrinol Metab 2007;92:65-69.
-9 Pivonello R, Ferone D, de Herder WW, et al: Dopamine receptor expression and function in human normal adrenal gland and adrenal tumors. J Clin Endocrinol Metab 2004;89: 4493-4502.

10 Miller JW, Crapo L: The medical treatment of Cushing's syndrome. Endocr Rev 1993;14: 443-458.

11 Petrossians P, Ronci N, Valdés Socin H, et al: ACTH silent adenoma shrinking under cabergoline. Eur J Endocrinol 2001;144:51-57.

12 Miyoshi T, Otsuka F, Takeda M, et al: Effect of cabergoline treatment on Cushing's disease caused by aberrant adrenocorticotropin-secreting macroadenoma. J Endocrinol Invest 2004;27:1055-1059.

13 Pivonello R, De Martino MC, Cappabianca $\mathrm{P}$, et al: The medical treatment of Cushing's disease: effectiveness of chronic treatment with the dopamine agonist cabergoline in patients unsuccessfully treated by surgery. J Clin Endocrinol Metab 2009;94:223-230.

-14 Isidori AM, Kaltsas GA, Pozza C, et al: The ectopic adrenocorticotropin syndrome: clinical features, diagnosis, management, and long-term follow-up. J Clin Endocrinol Metab 2006;91:371-377.

15 Daly AF, Rixhon M, Adam C, et al: High prevalence of pituitary adenomas: a crosssectional study in the province of Liege, Belgium. J Clin Endocrinol Metab 2006;91: 4769-4775.
16 Easterbrook PJ, Berlin JA, Gopalan R, Matthews DR: Publication bias in clinical research. Lancet 1991;337:867-872.

17 Callaham ML, Wears RL, Weber EJ, Barton C, Young G: Positive-outcome bias and other limitations in the outcome of research abstracts submitted to a scientific meeting. JAMA 1998;280:254-257.

18 Schade R, Andersohn F, Suissa S, Haverkamp W, Garbe E: Dopamine agonists and the risk of cardiac-valve regurgitation. $\mathrm{N}$ Engl J Med 2007;356:29-38.

19 Zanettini R, Antonini A, Gatto G, et al: Valvular heart disease and the use of dopamine agonists for Parkinson's disease. N Engl J Med 2007;356:39-46.

20 Lancellotti P, Livadariu E, Markov M, et al: Cabergoline and the risk of valvular lesions in endocrine disease. Eur J Endocrinol 2008; 159:1-5.

21 Illouz F, Dubois-Ginouves S, Laboureau S, Rohmer V, Rodien P: Use of cabergoline in persisting Cushing's disease. Ann Endocrinol 2006;67:353-356

22 Godbout ABH, Babin S, Sabourin A, Lacroix A: Cabergoline in the longterm treatment of Cushing's disease: preliminary safety and efficacy results of a phase II study. Endocrine Society's 89th Annual Meeting, 2007.

23 Vilar L, Naves LA, Azevedo MF, et al: Effectiveness of cabergoline in monotherapy and combined with ketoconazole in the management of Cushing's disease. Pituitary 2010;13: 123-129. 